\title{
Pension Program for Informal Workers: Finding out Indigenous Knowledge-based Alternative Model of Pension
}

\author{
R.Wiliandri ${ }^{1,2, *}$ \\ ${ }^{1}$ Department of Management, Faculty of Economics, State University of Malang, Indonesia \\ ${ }^{2} \mathrm{Ph} . \mathrm{D}$ student in Leiden Ethnosystem and Development Programme, Leiden University, Netherlands \\ *Corresponding author: ruly.wiliandri@gmail.com
}

\begin{abstract}
In 2015, the Indonesian Government enacted the regulation concerning the pension system. This pension system was adopted from the national social security system (SJSN). However, the pension reform has focused mainly on the formal sector. The National Administering Body of Social Security for Employment (BPJS Employment) stated that many workers in Indonesia are not yet registered in the pension program. Therefore, the participation of informal sector workers in the pension program is quite low. The article aims to describe how informal workers who live dominantly in the village plan their finance related to their pension or when they enter their old age. The possibility of not being able to be engaged with the pension program implemented, and the role of the local custom institutions in helping the people plan their indigenous-based pension. This is a qualitative research, data was collected through interview and documentation. This research was conducted in Ngadisari village of Tengger area, in which local wisdom is used as the approach in the research. The research found that Tengger people save money for their old age. They also keep their own tradition such as Sayan and the concept of Catur Guru Bakti as the social security system to guarantee and protect the elderly people, which is important for the socio-economic development of the indigenous ethno-cultural population of Tengger.
\end{abstract}

Keywords: ethno-culture of Tengger, financial plan, informal workers, indigenous knowledge, pension program

\section{INTRODUCTION}

According to Cuevas et al., it is important to know the official international standard definition about informal worker. Based on the Seventeenth $\left(17^{\text {th }}\right)$ International Conference of Labour Statisticians (ICLS) in 2013, it defines informal employment as "employees are considered to have informal jobs if their employment relationship is, in law or in practice, not subject to labour legislation, income taxation, social protection or entitlement to certain employment benefits (advance notice of dismissal, severances of pay, paid annual or sick leave, etc.)". Note that this definition is made in regard to the primary job or occupation, even as a person can simultaneously have two or more jobs.

The Indonesian Central Bureau of Statistics (BPS) states that formal and informal work can be identified based on the main employment status. BPS categorize the people who work based on informal work such as self employment, employer with temporary labors, casual employee in agriculture, casual employee in non-agricultural sectors, and unpaid worker/working in family business. Meanwhile, formal work involves being assisted by permanent labors and employees. BPS also categorizes the people who work based on their sector or activity such as agriculture, industry, construction, commerce, transportation, warehouse and communication, 
finance, social services, others (mining, electricity, gas, and water).

According to BPS, the number of workers per February 2016 accounts for 120.6 million workers, in which 50.3 million people $(41.72 \%)$ work in formal sectors and 70.3 million people $(58.28 \%)$ work in informal sectors. People with the highest main job type fall on those working in agriculture (38.29 millions), followed by those working in commerce (28.50 millions) (p.54). It can be concluded that the number of informal workers is considered high in Indonesia.

The high number of workers in agricultural sectors implies that agriculture still accounts for the sector or activity of the majority of Indonesians who generally live in villages. According to the data record in BPS in 2015, informal workers mostly come from villages, and their number reaches 37.87 million people or $60.43 \%$, while the formal sectors are dominated by people from cities whose number reaches 41.09 million people or $70.61 \%$. This is in line with the research conducted by Ikhsan, implying that informal jobs are more dominant in villages than in cities. Besides, Nazara also stated that the majority of people as informal workers lived in village areas.

Social security is not only given in formal sectors, since the government has conducted some reformation related with social security by implementing National Social Security System (SJSN) as stated in the Social Security Legislation No. 40 Year 2004 about National Social Security System.

Government has approved the Social Security Law 24/2011 on the National Administering Body of Social Security (BPJS). Since 2015, BPJS for employment has implemented 4 social security programs which involve work accident program (JKK), death insurance (JKM), Old Age Savings Program (JHT), and Pension Program (JP). While JKK and JKM give protection, JHT and JP focus on the welfare of the societies. Especially for the implementation of pension security, the government has issued the regulation No. 45 Year 2015 concerning the implementation of pension program.
Based on the scope of participants and the program in BPJS Employment, the participants may involve those receiving wages are categorized as formal workers, and those not receiving wages are called informal workers (p.48).

As reported by BPJS Employment, up to December 31, 2015, active employees who are protected under the social security accounted for 19,275,061 with the following details: participants receiving wages accounted for $18,988,996$ people and those receiving no wages accounted for 286,065 people. Meanwhile, according to the social security program especially for those who do not receive wages such as JKK, JKM, and JHT, there were only 370,302 workers in 2015, smaller than the number targeted which should be 2 millions.

Based on the above background, the research question in this paper is the participation of informal sector workers in the social security particularly pension program which is quite low. Meanwhile, the majority of people as informal workers lived in village areas. In this research, the local peoples' systems of knowledge and practice are used as an approach of 'development from the bottom' in order to increase the participation of local community members and as such sustainable community development. This is in line with the summary by Slikkerveer and Ismawan, stating that:

In this new orientation in development cooperation, the local peoples' systems of knowledge and practice are used as a starting point for a strategy of 'development from the bottom' rather than 'development from the top' in order to enhance the participation of local community members and as such sustainable community development (p.32).

The research aims to describe how informal workers who live in Tengger village in East Java plan their pension or when they enter their old age and the role of the local custom institutions in helping the people plan their indigenous-based pension. This study expects to provide a contribution to culturallyappropriate and local community-based policy 
planning and implementation for the pension program in the research area.

\section{METHOD}

This paper discusses about pension program which is being implemented in Indonesia and how informal workers, especially farmers, could be given access to the program. This preliminary research was conducted in Ngadisari village of Tengger area, in which local wisdom is used as the approach in the research.

This research used the qualitative method, which was conducted by involving one or two individuals. The qualitative data was collected through interview and documentation. In performing the interview, face-to-face interview was carried out with an informant, while in documentation, statistical data were collected from the research centers, statistics office, and village office.

The area of research, the village of Ngadisari, was selected as the research location due to the fact that most of its local people still rely on farming lands to survive and they work as farmer. Moreover, they are still bound with their local tradition of Tengger.

The informant, also called as a participant, comprised two key persons such as the exheadman of Ngadisari, Sukapura sub-district, district of Probolinggo, who is currently serving as a member of the Regional House of Representatives, district of Probolinggo and the headwoman of Ngadisari village, Sukapura sub-district, district of Probolinggo.

This research focuses on events experienced by the informants during their time serving as a leader in Ngadisari village and the perception and meaning in their experience as told in the interview, especially those related to pension planning of the societies.

\section{RESULTS}

The essence of Financial Plan Indigenousbased Pension

The Tengger people's habit in Ngadisari Village to save money is passed from generation to generation, recalling that they are living on an active volcanic area and are at high risk of volcanic eruption. This geographical reason raises the people's awareness of being financially prepared for their old age. In the past, people of this village put their money somewhere in the house or inside a bamboo tube. The bamboo tube wherein money is put is commonly known as bumbung pring. This impractical way of saving money brought the headman to the idea of coordinating a partnership with Bank Rakyat Indonesia for savings and loan program for the people in Ngadisari village in 2012. Maliki stated that most Indonesian elderly finance their retirement using their reallocated assets. They accumulate assets when they are productive and earn cash from their assets to finance the retirement consumption as well as to support other nonproductive household members.

\section{"Catur Guru Bakti" and "Sayan" Tradition of} Tengger People to ensure the Pension

The majority of Tengger people in the village of Ngadisari, Sukapura sub-district, district of Probolinggo are still strongly engaged to their local tradition and culture. The whole area of the village comprises $4,993 \mathrm{~km}^{2}$ of land, 1,558 people, and 507 heads of household. There are as many as 749 males and 809 females (p.13$15)$, and those above 55 years old account for 274 people.

According to the level of prosperity, there are 80 household-heads categorized as preprosperous family, 62 household-heads as prosperous family I, 169 household-heads as prosperous family II, and 195 household-heads as prosperous family III. In term of their beliefs, most of the people adhere to Hinduism accounting for 1,504 people, while the rest adhere to Islam and Catholic for 53 people and 1 person, respectively (p.67)

Most people in Ngadisari village make their living from agricultural sectors, and farming is their main job with 1,151 people working as farmers. Potato, cabbage, lettuce, carrot, tomato are some of the main agricultural produce in the village to be sold in the market to help them save money for their pension time (p.36).

Ownership of farming land in the village is considered crucial, and it is believed that 
selling land to other parties outside the village is not acceptable. Therefore, the headman and the vice-governor of Probolinggo came up with an idea to issue local wisdom based certificate to give protection to the people of the village in term of the ownership of their farming lands. With this system, it will not allow the landowners to sell the lands to other parties, but to the people of Tengger.

To provide pension to the people, Tengger people of Ngadisari village firmly hold the local wisdom with the concept of Catur Guru Bakti and Sayan tradition. Catur Guru Bakti means four gurus that must be respected in a quest of sacredness and essence of life. Obedience to God is the first Guru called Swadyaya. Parents represent the second Guru called Rupaka, as parents have devoted their life to raising their children. Their endless service to the children makes the youth owe their parents their body, life, and service. The third Guru is Guru Waktra who is represented by educators who teach at school, and the fourth Guru is called Guru Wisesa who is presented by the government who has been majorly involved in protecting its people, and bringing them to prosperity.

The position of parents as Guru Rupaka obliged people to respect, guard, and take care of their parents till their old age. This responsibility has been a part of their culture. It is common for parents and children in the village to live close by; most of them even live under the same roof. This situation gives children access to help their parents in case of sickness or death. Moreover, when financial problems occur among their children, close relatives usually help them cope with the condition. All those examples imply that people of the village put kinship as a priority.

Sayan, also called as gotong royong or mutual cooperation, is described as mutual help among people, friends, relatives, which is given voluntarily. The implementation can be seen in construction work such as building a house, preparing festivity for ritual purpose, wedding party, and funeral. This tradition shows that they live in togetherness and have high social awareness in Ngadisari village, and this once brought the village to an achievement in which it won the first place in the national gotong royong competition in 2013.
The Sayan tradition also takes part in giving security to their pension. Meanwhile, social investment can be given through buwuh (giving money or things to those having festivities or to a married couple at their wedding party) and srawung or commonly known as socializing as a tradition, which can serve as savings when they grow old. Interestingly, the people of Tengger who have assets will be recorded and listed by a headman/headwoman of the village. The book which is used to record and list the asset for all people in Ngadisari Village called Bukoan .

Another example reflecting a Sayan tradition is mbiyodo or nyinoman which is also seen as a form of mutual cooperation (gotong royong). Basically, both terms refer to the same activity in which they provide help to people who are having a festivity or a wedding party by coming over their house to help with the preparation without any invitation. Mbiyodo refers to females while nyinoman to males. This tradition has been long established, and it does not require the helpers to bring food or money as a contribution, but they help by getting involved in the preparation.

It can be concluded that the social investment such as srawung is essential among the people of Tengger as well as the Sayan tradition. It is believed that good social investment may bring people to prosperity.

The data of prosperity level in Ngadisari village shows that the people in the village is categorized as prosperous families, in which there are only 39 people out of 1,558 who are subsidized with rice for the poor (Raskin) by the local government of Probolinggo. There is also a tradition called Mborong Kerso, in which senior citizens (aged 50 and over) are not obligated to be involved in social activities such as village patrol, community service, meeting at village office, however they are still invited to come as to show some respect to them, and to allow them to socialize "guyub". When there is a physical obstacle that stops the elderly from joining social activities, they usually say a prayer to wish the society the best of luck "mangestoni". 


\section{DISCUSSION}

\section{Pension System in Indonesia}

From the aforementioned, it can be concluded that for the pension program, the government is focusing on formal sectors workers involving workers who receive wages working under the government and non-government. On the other hand, there is still no clear regulation which regulates the pension program for workers without wages (informal workers). Hu and Stewart stated that informal sector workers do not participate in pension systems due to the the strict criteria involved are too onerous, such as on terms of contribution requirements, vesting policies and requirements on the governance structure of pension funds itself. Therefore, it may be necessary to relax some requirements to a level which is consistent with the situation relating to informal sector workers such as flexibility in terms of contributions (irregular contributions) and flexibility in terms of withdrawals for example, when there is a good harvest, due to good weather conditions, farmers can afford larger pension contributions than normal. However, if bad weather conditions, farmers may not have sufficient funds to meet their basic needs.

Related to the pension time, informal workers are required to plan their finance well, including preparing their savings for their pension time, so that they can still maintain their welfare even when they grow old.

The lack of awareness among societies in informal sectors of social security program administered by BPJS Employment is triggered by unclear regulation for the pension program. Moreover, only a few of them are familiar with the importance of such a social security program. Therefore, the introduction of SJSN to societies serves as one of the most important aspects in implementing SJSN. This may be hampered by the skill of informal village workers required to manage their finance. Villagers mostly receive only a small amount of money in their wages or salary, and it is quite uncertain. Consequently, paying monthly contribution for social security may be something far fetched for most of them. This leads to another difficulty in term of raising the awareness of informal workers of the essence of social protection for each individual.

Financial education can provide information on the characteristics of pensions and retirement savings plans so that the individual understands what actions he needs to take with respect to each of the options. For example, he will know that he will need to bear more of the responsibility (and risk) for this own retirement savings if he has a retirement savings plan than if he has a pension. He will know that in the case of a retirement savings plan he will have to make decisions about participation, contributions, and asset allocation. Financial education is needed to ensure that retirement income and pensions are adequate, and in addition financial education is increasingly needed to close the gap between the retirement people's want and what they can afford (p.12-13).

One of the factors causing low participation of informal workers for social security, especially in rural areas is because they show with each other mutual assistance (gotong royong), kinship, family, and others. This is in line with the research conducted by $\mathrm{Hu}$ and Stewart, who stated that "the challenge is greater to getting informal sector workers to participate in pension schemes due to the traditional role of family support in pension provisioning" (p.2).

According to Slikkerveer, the majority of people living in rural areas, with their tradition of workers in typical job field like fisheries and farming, which have been kept for years, are able to survive on their own. They also believe that kinship, family ties, and mutual aids should be put as a priority as one of the survival methods.

The development of microcredit and microenterprise had become a major anti-poverty intervention instrument, followed by new micro-services of small savings and microinsurance, provided by most microfinance institutions (MFIs) (p.3). As $\mathrm{Hu}$ and Stewart stated that government can use microfinance institutions as partners who give alternative finance providers, such as the retirement related pension provisioning to the informal workers in rural areas. 
Uthira et al. stated that the micro-pension scheme is based on voluntary saving by small and unorganized workers so as to provide them with a regular flow of pension as annuities for the old age which accumulated over a long period and intermediated through financial and capital markets by a professional fund manager. The micro finance institutions should provide the service of micro pension scheme. The micro pension is targeted towards individuals in the unorganized sector, an economically weaker rural in order to protect them againts old age income security.

In this paper, Tengger people in Ngadisari village have the custom to save their money which has been passed from generation to generation. They voluntarily save their money with no fixed amount in some local village organisations. Sometimes, if they have much money from their agricultural product, they save their money to the BRI in Ngadisari village. The goals of their savings are to fulfill their need, but most of them have not prepare their savings to old age or joined the pension program. This happened because people of the village prioritized local wisdom with the concept Catur Guru Bakti and Sayan tradition to guarantee their pension as a priority, and they are not familiar with the pension program. In fact, people in Ngadisari village have not been registered as participants of the pension security program yet.

In general, the results are expected to offer a deeper understanding of the indigenous knowledge systems, practice and belief, of the Tengger people in Ngadisari, rooted in their local institutions in which Catur Guru Bakti and Sayan tradition are the particular form of social security for the elderly to old age. Additionally, the results of this study are expected to provide a contribution to culturally-appropriate and local communitybased policy planning and implementation for the care of the elderly in the research area of East Java. In this way, the strong cultural identity and function of the sayan and concept of Catur Guru Bakti can be integrated into an improved local institution for the care of the elderly among the Tengger people in the future.

This research was conducted in Ngadisari village which is located in one of the Tengger areas in East Java. My suggestion for further studies is to expand the research area in Tengger to people in another village. So, we can have a deeper understanding of the indigenous knowledge systems, practice and belief of the Tengger people in East Java in planning their old age.

\section{CONCLUDING REMARKS}

The Tengger people in Ngadisari village implemented the Catur Guru Bakti and Sayan tradition as a social security system and to guaranty and protect their elderly people and it is important for the socio-economic development of the indigenous Tengger ethnocultural population group in East Java, as well as of similar groups elsewhere in Indonesia, in which rural communities among such various ethno-cultural groups have developed and maintained over many generations. Their tradition to care for their elderly people is expected to be considered in national policy planning and implementation of social security system for the elderly in the local institutions with their particular values, needs and expectations, which is encapsulated in their indigenous systems of knowledge, belief and practice.

\section{Conflict of interest: none declared}

\section{ACKNOWLEDGEMENT}

The author wishes to thank Mr. Supoyo and Mrs. S. Wahyuni as participants or informants in this research. Thanks to Prof. Dr. L.J. Slikkerveer as my supervisor who gives me the opportunity to write this paper and to present it at the International Conference of IMM 2016 in Bandung.

\section{REFERENCE}

1. Cuevas S, Mina C, Barcenas M, Rosario A. Informal employment in Indonesia. Manila: Asian

Development Bank; April 2009. ADB Economics Working Paper Series, No. 156.

2. Badan Pusat Statistik. Agustus 2016. Laporan bulanan data sosial ekonomi. Edisi 75. Available from: http://www.bps.go.id/website/pdf_pub likasi/Laporan-Bulanan-Data-Sosial- 
Ekonomi-Agustus-2016.pdf [Accessed 20th August 2016].

3. Ibid. p.54

4. BPS. Data sosial dan kependudukan. Available from: http://bps.go.id [Accessed 25th August 2016].

5. Ikhsan M. Peran pasar tenaga kerja yang fleksibel dalam mengatasi pengangguran. Universitas Indonesia: Lembaga Penyelidikan Ekonomi dan Masyarakat (LPEM); 2005. LPEM Working Paper No.11.

6. Nazara S. 2010. Ekonomi informal di Indonesia: ukuran, komposisi, dan evolusi (organisasi perburuhan internasional). Available from: http://www.ilo.org/wcmsp5/groups/pu blic/---asia/---ro-bangkok/---ilojakarta/documents/publication/wcms_ 145402.pdf [Accessed 23th August 2016].

7. Badan Penyelenggara Jaminan Sosial Ketenagakerjaan. September 2015.

Rencana strategis BPJS

ketenagakerjaan 2014-2018 perubahan II. Available from: http://www.bpjsketenagakerjaan.go.id/ assets/uploads/tiny_mce/KIP/2007201

6_120953_Publish_Renstra\%20BPJS

\%20Ketenagakerjaan\%2020142018.pdf [Accessed 21st August 2016].

8. Badan Penyelenggara Jaminan Sosial Ketenagakerjaan. 2015. Resume laporan pengelolaan program (audited). Available from: http://www.bpjsketenagakerjaan.go.id/ assets/uploads/tiny_mce/Annual\%20R eport/22062016_105942_Resume_LP P_BPJS_Ketenagakerjaan.pdf [Accessed 21st August 2016].

9. Slikkerveer LJ, Ismawan B. Introduction to integrated microfinance management in indonesia. In: Slikkerveer LJ. (Ed.) Handbook for lecturers and tutors of the new master course on integrated microfinance management for poverty reductiuon and sustainable development in indonesia (IMM). Leiden University, The Netherlands: LEAD; 2012. p. 17-41.

10. Creswell JW. Research Design Pendekatan Metode Kualitatif,
Kuantitatif, dan Campuran. Edisi

Keempat. Yogyakarta: Pustaka Belajar; 2016.

11. Supoyo. An ex-headman of ngadisari village, sukapura sub-district, district of probolinggo, who is currently serving as a member of regional house of representatives, district of probolinggo. Personal communication. 28th August 2016.

12. Maliki. Supporting system among the elderly in Indonesia. Available from: http://www.umdcipe.org/conferences/ policy_exchanges/conf_papers/Papers/ 2081.pdf [Accessed 27th August 2016].

13. Badan Pusat Statistik Kabupaten Probolinggo. Agustus 2016. Kecamatan sukapura dalam angka. Available from: https://probolinggokab.bps.go.id/webs ite/pdf_publikasi/KecamatanSukapura-Dalam-Angka-2016.pdf [Accessed 30th August 2016].

14. Ibid. p. 67

15. Ibid. p. 36

16. Dinas Komunikasi dan Informatika Pemerintah Provinsi Jawa Timur. 10 Jul 2015. Tanah Bromo Tengger tidak dapat diperjualbelikan. Available from: http://kominfo.jatimprov.go.id/read/u mum/45648 [Accessed 28th August 2016].

17. Supoyo. An ex-headman of ngadisari village, sukapura sub-district, district of probolinggo, who is currently serving as a member of regional house of representatives, district of probolinggo. Personal communication. 28th August 2016.

18. Ibid.

19. Ibid.

20. Wahayu S. A headwoman of ngadisari village. Personal communication. 28th August 2016.

21. Ibid.

22. Hu Y, Stewart F. Pension coverage and informal sector workers: international experiences. $O E C D$ Working Papers on Insurance and Private Pension. 2009; 31:1-23. Available from: doi: 10.1787/227432837078 [Accessed 31th August 2016]. 
23. Basuki RN. 14 December 2015.

Pemerintah dorong pekerja informal daftar BPJS. Available from: http://www.cnnindonesia.com/nasiona 1/20151214044802-20-97966/

[Accesed 28th August 2016] dan ADY. Pekerja sektor informal di asean minim jamsos. Available from: http://www.hukumonline.com/berita/b aca/lt52c5587511304/[Accesed 28th August 2016].

24. Organisation for Economic Cooperation and Development (OECD). Financial education and saving for retirement. Available from: http://www.oecd.org/finance/privatepensions/39197801.pdf [Accessed 1st September 2016].

25. Hu Y, Stewart F. Pension coverage and informal sector workers: international experiences. $O E C D$ Working Papers on Insurance and Private Pension. 2009; 31:1-23.

Available from: doi: 10.1787/227432837078 [Accessed 31th August 2016].

26. Slikkerveer LJ. General introduction: indigenous knowledge systems for poverty reduction. In: Slikkerveer LJ. (Ed.) Handbook for lecturers and tutors of the new master course on integrated microfinance management for poverty reductiuon and sustainable development in indonesia (IMM). Leiden University, The Netherlands: LEAD; 2012. p.1-14.

27. Slikkerveer, L.J. 'Ethnoscience, 'TEK' and its Application to Conservation. In: D.A. Posey (ed.), Cultural and Spiritual Values of Biodiversity: A Complementary Contribution to the Global Biodiversity Assessment. London/Nairobi, Intermediate Technology Publications/United Nations Environment Programme (UNEP); 1999.

28. Hu Y, Stewart F. Pension coverage and informal sector workers: international experiences. $O E C D$ Working Papers on Insurance and Private Pension. 2009; 31:1-23. Available from: doi: 10.1787/227432837078 [Accessed 31th August 2016].

29. Uthira D, Manohar, HL. Economic Implications and Sustainability of Micropensions in the Era of Pension Reforms in India. International Research Journal of Finance and Economics. 2009; ISSN 14502887(24): 36-47. Available from: http://www.pensiondevelopment.org/d ocumenten/Micropensions\%20in\%20I ndia\%20-\%20Uthira.pdf [Accessed 31th August 2016]. 